\title{
Weakness of will: philosophical and theological theories of action
}

\section{Saarinen, Risto}

Brepols

2006

Saarinen , R 2006 , Weakness of will: philosophical and theological theories of action . in Intellect et imagination dans la philosophie medievale . Brepols, Turnhout, pp. 53-71.

http://hdl.handle.net/10138/42027

acceptedVersion

Downloaded from Helda, University of Helsinki institutional repository.

This is an electronic reprint of the original article.

This reprint may differ from the original in pagination and typographic detail.

Please cite the original version. 


\section{Weakness of Will: Philosophical and Theological Theories of Action}

Risto Saarinen (University of Helsinki)

\section{Modern Authors on Aristotle's akrasia}

One feature of a genuine philosophical problem is that it can become relevant in new and unexpected contexts which are independent of the earlier historical treatment of the problem. Aristotle's akrasia, "weakness of will," exemplifies this feature in a paradigmatic manner. A weak-willed person, as Aristotle says in Nicomachean Ethics, Book VII, wants to do good, but he nevertheless acts against his own better judgment. The existence of akrasia is a philosophical problem, because Socrates held that no one acts against his or her own knowledge. But if this is the case, then there are no truly akratic actions. On the other hand, weakness of will seems to be a common phenomenon. How is this phenomenon explained? Aristotle solves the problem by saying that the weak-willed person ignores something at the very moment of akratic action. Even if he or she claims to know that she is doing wrong, she does not use her knowledge in a clear and distinct manner. In this sense Aristotle denies the possibility of a clear-eyed akrasia. In other words, weak-willed behavior is only possible if something remains inconsidered during the decision-making and the action. ${ }^{1}$

During the last decades, weakness of will has again become a relevant issue in contemporary philosophy. Aristotle is employed as the starting-point of this contemporary discussion, but the discussion itself is systematic and philosophical rather than historical. The beginnings of contemporary discussion are characterized by the attempt to reduce the number of mental concepts and to develop an account of intentional action which can dispense with the notion of will. This line of analytic philosophy, initiated by thinkers like Gilbert Ryle and G.E.M. Anscombe, soon realized that in Aristotle's theory of action we have a historical theory which does not apply a concept of autonomous will but operates with a "forward" connection between judging a course good and pursuing it. ${ }^{2}$

But if we are to understand intentional action as the outcome of rational decision-making process, which does not need an additional free will, we are soon faced by the old problem of Aristotle. This was realized by philosophers like R.M. Hare who denied the possibility of clear-eyed akrasia. ${ }^{3}$ On the other hand, analytical

1 For an overview of the philosophical discussion, cf. Charlton, W., Weakness of Will: A Philosophical Introduction. London: Duckworth 1988; and Gosling, J., Weakness of Will. London: Routledge 1990.

22 See Charlton 1988, 10.

$3 \quad 3$ For the older contemporary discussion, see Mortimore, G., ed., Weakness 
philosophy also attempted to offer solutions which could make akrasia a real possibility without postulating additional mental concepts. The best known and most discussed of these solutions is the one put forward by Donald Davidson. In his article "How is Weakness of Will Possible"4 Davidson claims that it is possible to affirm, simultaneously, the following three statements:

$\mathrm{P} 1$ : If an agent wants to do $\mathrm{x}$ more than he wants to do $\mathrm{y}$ and he believes himself free to do either $\mathrm{x}$ or $y$, then he will intentionally do $x$ if he does either $x$ or $y$ intentionally.

P2: If an agent judges that it would be better to do $x$ than to do $y$, then he wants to do $x$ more than he wants to do $y$.

P3: There are incontinent actions.

We see that P1 establishes a forward connection between willing and doing and P2 a forward connection between judging and willing. How can Davidson justify that there are nevertheless akratic, i.e. incontinent actions?

Davidson makes the existence compatible with the "forward connection" expressed in P1 and P2 by distinguishing between two kinds of jugdments: prima facie (conditional, all-things-considered) judgments, on the one hand, and unconditional (sans phrase, absolute) judgments, on the other hand. He says that an incontinent person judges that, all things considered, it would be better to do $y$ than to do $\mathrm{x}$. But this is a conditional judgment, whereas P2 is an absolute judgment. A judgment which proceeds from taking into account all relevant circumstances and thus bases itself upon them, is a judgment relative to the available evidence and thus it remains conditioned by the circumstances.

The akratic person has thus in her mind two judgments: an absolute judgment commanding $\mathrm{x}$ and a conditional forbidding judgment, saying that all things considered $x$ should not be done. But now the logical problem has disappeared, since a conditional judgment cannot conflict with any unconditional judgment. This

of Will. London: Macmillan 1971; Charlton 1988, 10.

${ }^{4}$ Davidson, D., "How is Weakness of the Will Possible". In Moral Concepts, ed. J. Feinberg, pp. 93-113, Oxford: Oxford University Press 1970. (Also in his Essays on Actions and Events, pp. 21-42. Oxford: Clarendon Press 1980.) The following description is taken from this article and from the subsequent discussion surveyed in both Charlton 1988 and Gosling 1990. Cf. also Saarinen, R., "John Buridan and Donald Davidson on Akrasia" Synthese 96, 1993, pp. 133-154. but note that the following interpretation of Davidson differs to some extent from the interpretation I offer in my essay of 1993. For a very thorough examination on Davidson's argument, see Peijnenburg, J., Acting against One's Own Best Judgement. Diss. Groningen: University Library Groningen1996. (also in: www.ub.rug.nl/eldoc/dis/a.j.m.peijnenburg as of April 2002). 
description of akrasia does not make weak-willed behavior psychologically understandable, since it is nevertheless odd that somebody acts against his or her better knowledge. Davidson is not giving a psychological rationale, but only solving the logical problem. It should also be noted that a conditional judgment is not meant to be a preliminary or incomplete judgment. On the contrary, it represents the "all-things-considered" reflection, whereas the absolute or unconditional judgment here stands for the hasty and inattentive estimation of the weak-willed person. But this estimation is unconditional or absolute in the sense that it prompts willing and doing, whereas a conditional judgment does not.

The merits of Davidson's discussion have been described as follows: "It is the first one to focus attention on the notion of the prima facie in practical thinking. This notion is of central importance both to the moral philosopher and to the philosopher of action. ... Moral philosophers ... tend to think that general moral philosophers purport to determine what is absolutely right and wrong, and not just right and wrong prima facie." 5

Two remarks should be made concerning this description. First, the distinction between "prima facie" and "absolute" judgments is more complicated. A prima facie judgment is something preliminary. But for Davidson both prima facie and all-things-considered denote conditions which make the judgment in some sense conditional. An "all-things-considered" judgment is in a some rather strong sense more thorough than an absolute judgment. But as a cause of willing an absolute judgment is more powerful than a conditional one.

Secondly, a historian of philosophy is immediately on the alert when somebody is reported to be the first to say something. If we look at the medieval moral philosophers, we can see that the Aristotelian tradition was very careful in its attempts to define the good judgment and how it prompts action. We may ask whether the right judgments described by medieval moral philosophers are in Davidson's classification "all-things-considered" judgments or "absolute" ones.

In the following I will examine some medieval explanations of akrasia and relate them to Davidson's discussion. My emphasis will be on philosophical texts (2-4), but I will also pay attention to some theological explanations. (6) I will argue that the medieval discussion shows important similarities with the contemporary philosophical debate on akrasia (5). I will finally (7) highlight one aspect of the medieval discussion which, in my view, has an even wider philosophical significance.

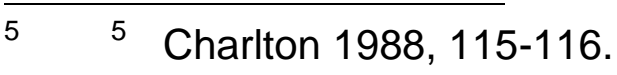




\section{Synesis as Good Judgment in Aristotle and Aquinas}

The following presentation employs the concept of synesis, a topic which was not dealt with in my book Weakness of the Will in Medieval Thought but which is nevertheless relevant for the medieval explanations of akrasia.

According to Aristotle, the good judgment which serves as basis of prudential action is formed by the virtue of synesis. Synesis is concerned with judging well and soundly (EN 1143a15) about things "which may become subjects of questioning and deliberation" (1143a6). Aristotle discusses the relationship of synesis to intellect, reason, and perception which are all active in the formation and use of the practical syllogism. In this context the Latin translation of EN states that intellectus as an intuitive mental capacity concerns the extreme terms of syllogism, whereas ratio pertains to the demonstrative reason. When a particular course of action is being deliberated, intellect and perception (sensus) are strongly related to each other, since the senses perceive the singular things upon which the intellect bases its universal generalization. Whereas in theoretical issues the intellect is dealing with universals, in practical syllogism it generalizes from the singular and particular things in a manner which is fundamentally dependent on singular facts. ${ }^{6}$

Although the Latin text of EN does not in particular relate synesis with perception, Aristotle in the context (EN 1142a24-30) clearly says that prudence deals with sensus. ${ }^{7}$ Thus it is natural to think that, insofar as the prudential capacity of judging well the particulars is concerned, synesis has to do with perception. Thomas Aquinas takes this step and teaches that the Greek word synesis or eusynesis means that the person has a good sensus. As good or right judgment synesis is made by the cognitive power as a clear apprehension of things. ${ }^{8}$ Synesis is the special judicative "use" of knowledge in prudential action, a use which presupposes learning and deliberation and which is followed by the actual command. ${ }^{9}$ In his Sententia libri

\footnotetext{
6 Aristoteles Latinus. Ed. L. Minio-Paluello, G. Verbeke. Vol. 26,1-3: Ethica Nicomachea (EN), ed. R.A. Gauthier. Leiden: Brill 1967. Translatio Grosseteste, recensio pura, p. 266, 13-23 (EN 1143a31-b5): "Sunt autem singularium et extremorum omnium operabilia. Et enim prudentem oportet cognoscere ipsa, et synesis et gnome circa operabilia. Hec autem extrema et intellectus extremorum in utraque. Et enim primorum terminorum et extremorum intellectus est et non racio. Hic quidem secundum demostraciones inmobilium terminorum et primorum, hic autem in practicis extremi et contingentis et alterius proposicionis. Principia enim eius quod est cuius gracia, ipse. Ex singularibus enim, universale. Horum igitur oportet habere sensum. Hic autem est intellectus."

7 Recensio pura, 262,23-263,3.

$8 \quad 8$ Thomas Aquinas, Summa theologiae (ST), II/II q51 a3.

$9 \quad 9$ Thomas, In Eth. VI Ic9 n 5,7-8.
} 
Ethicorum Thomas remarks that in addition to the external perception we find an internal sense at work, a sensus which Thomas calls intellect as related to the singulars. ${ }^{10}$

Thomas's discussion of synesis as right judgment already reveals some features on how medieval philosophy understood the moral judgments. Since ethics deals with a singular and contingent subject matter and since the judgment is highly dependent on perception, the moral judgments are qualified by these circumstances. Thomas says that our intellect is twofold: whereas in theoretical matters it operates with universals, in practical matters it deals with the minor premise of the practical syllogism, and in so doing it employs both the perception of the externals and its own capacity for internal sensus, an estimative power that, with the help of perceptual information, formulates the minor premise. ${ }^{11}$

If we explain Aristotle's synesis as a correct awareness of the situation, we can say that already in Thomas the emerging right judgment is, in Donald Davidson's vocabulary, an all-things-considered judgment rather than an absolute judgment. This is so because, in moral issues, the emerging judgment is relative to and dependent on the contingent facts of which we can have no universal truths. But probably for Aquinas, Davidson's distinction would not make much sense since absolute judgment in Davidson's terms would simply be a judgment that prompts action. And for Aquinas right moral judgments normally do prompt actions although they are dependent on particular facts.

In the following I will argue, however, that the late medieval discussion after Thomas Aquinas begins to display a deeper awareness of the issue how different types of judgments yield different results with regard to the "forward connection" between thought and action. This is especially clear in John Buridan's treatment of synesis, prudence, and weakness of the will.

\section{Buridan on Synesis and Prudence}

Thomas's view of synesis as good or right judgment is important for this development. The first Franciscan commentator of Ethics, Geraldus Odonis, compiles and systematizes Thomas's terminology into a threefold scheme in which the deliberative part (eubulia), the judicative part (synesis) and the actually commanding part of prudence are all subdivided into four partial powers or abilities. When they are discussing the partial virtues of prudence, both Odonis and Buridan

\footnotetext{
$10 \quad 10$ In Eth. VI Ic9, n.15.

1111 In Eth. VI Ic9, n15. Cf. Doig, J., Aquinas's Philosophical Commentary on the Ethics: A Historical Perspective. Dordrecht: Kluwer, pp. 258-260.
} 
quote the following memory verse:

[Eubulia:] Qui solers, docilis, memor est, qui vir rationis

Rectum consilium perficit ille suum.

Tardus, et indocilis, ignarus, et immemor extans

Rectum consilium non facit ille suum.

[Synesis:] Hinc intellectus, sensus, cautela malorum

Mens circumspecta, dant bona iudicia.

Mens hebes, insensata maneas, incauta periclis, Incircumspecta, dant mala iudicia.

[Commanding prudence:] Certa ac suasiva mens, constans atque benigna

Utile praeceptum perficit ipsa suum.

Ambiguus, fatuus, inconstans atque malignus

Vanum praeceptum construit ipse suum.

[Executive act:] Si curo, vigilo, si diligo, solliciterque,

Utiliter perago, quae peragenda volo.

Nec somnolenta, nec mens improvida felix,

Nec torpens animus, nec vagabunda manus. ${ }^{12}$

Let us more closely examine the philosophical issue explained in the context of this poem. John Buridan follows Odonis in his presentation of the subvirtues. Moreover, in his discussion of weakness of will Buridan constructs his view of syllogistic judgment in keeping with his discussion of synesis. I will therefore outline the content and the philosophical use of the relevant passages as they stand in Buridan. ${ }^{13}$

For Buridan, prudence consists in the totality of (1) deliberation (consilium/ eubulia), (2) judgment (iudicium/ synesis) and (3) the resulting command and (4) its execution. Prudence is thus not one simpliciter, but it is nevertheless a unified whole which is constituted by these parts. ${ }^{14}$ Prudence exercises a threefold or fourfold

1212 John Buridan, Quaestiones super decem libros Ethicorum. Paris 1513. Reprint Frankfurt: Minerva 1968, fol. 134va-vb. Cf. Geraldus Odonis, Sententia et Expositio cum quaestionibus super libros Ethicorum. Venice 1500, fol. 134 ra-va; Walsh, J. J. "Some Relationships between Gerald Odo's and John Buridan's Commentaries on Aristotle's Ethics" in: Franciscan Studies 35, 1975, pp. 237-275; here: pp. 242-244.

13 For a more detailed discussion, cf. Saarinen, R. "The Parts of Prudence: Buridan, Odonis and Aquinas" in: Dialogue (forthcoming).

${ }_{14}^{14}$ Buridan 1513, $134 \mathrm{rb}$ : "Dicendum est (ut magis mihi videtur) quod prudentia perfecta secundum quam homo dicitur simpliciter prudens, homo non solum prudens consiliator, aut prudens iudicator, aut prudens preceptor, vel exsequtor. Non est unus habitus unitate simplici sed unitate ordinis et connexionis multarum partium ab 
function: the first function (consilium) deliberates the available means. The second function (iudicium) judges over these means. The third function gives the command to act and the fourth function is the execution itself. Buridan remarks, however, that the fourth function, in his opinion, is not an elicited act and thus does not belong to the intellectual virtue of prudence but rather to the will as the dynamic part of the soul. ${ }^{15}$

Buridan goes on to outline the parts of prudence in an even more detailed fashion. The first, second and third functions, presented above, can all be subdivided into four parts. The inventive and deliberate part can (1) employ shrewdness or skill in conjecture (solertia, Gr. eustochia), as Aristotle says (EN 1142b1-5). Furthermore, the role of eubulia is divided into three: (2) as memory it records the material presented to it, (3) as reason it brings this material into consideration, and (4) as learning ability (docilitas) it equips the person with the capacity to become informed. The good counsel needs all of these four subdivisions, or abilities, in order to emerge in a perfect fashion. ${ }^{16}$

The second function, synesis, judges the material presented to it by good counsel. It employs four abilities, two of which pertain to the major premise of the practical syllogism, two others to the minor premise. Whereas (1) the intellect (intellectus) is able to make a correct estimation of the major premise, (2) perception (sensus) apprehends the concrete case expressed by the minor premise. Possible defects concerning the major premise are controlled by (3) circumspection or watchfulness which recollects all relevant general circumstances. Around the minor premise (4) caution exercises a similar function when it investigates the particular problems related to it. ${ }^{17}$ We may note here that synesis for Buridan is related to sensus in its judicative acts (perception, caution) concerning the minor premise. But synesis is

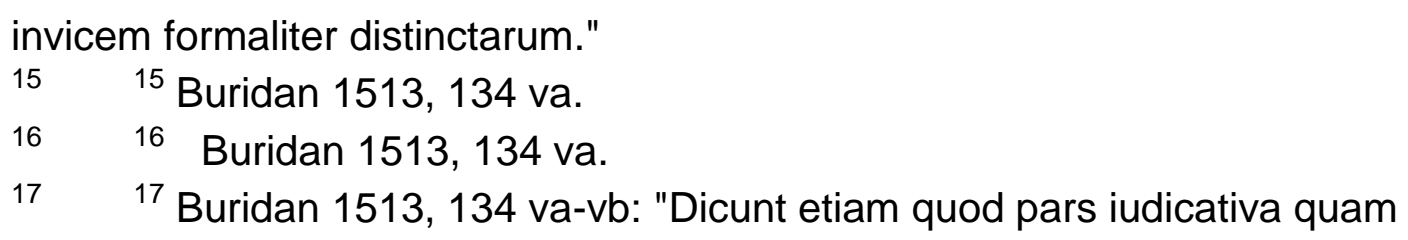

Aristoteles vocat synesim quattuor habet partes vel habilitates exigit sine quibus non potest ipsa esse bona et perfecta. Quoniam cum de conclusione fiat iudicium supet premissas, oportet sana capere maiorem et minorem et excludere defectum a maiori et minori. Conceptus igitur maioris est sana existimatio finis et legis propter quam et secundum quam dicendum est sic operandum esse in tali casu, et vocatur intellectus. Conceptus autem minoris est sana apprehensio presentis operabilis quod agitur vel circa quod agitur, et vocatur sensus, quia particulare agibile mediante sensu ab intellectu comprehenditur. Defectus autem excluditur a maiore per recollectionem circumstantiarum omnium que debentur operi, et huiusmodi recollectio vocatur circumspectio. A minori vero defectus excluditur per discretionem bonorum et malorum possibilium evenire actui vel operi, quam discretionem macrobius vocat captionem vel cautellam." 
equally strongly connected with the universal major premise in its acts of intellectus and circumspection.

The third function, command to act, also must meet four requirements, two of which pertain to the intellect, two to the appetitive powers. First, (1) a determination with certainty is needed. The intellect further needs (2) an effective persuasion (suasio efficax) in order to convince the appetitive powers properly. A persuasion which remains ambiguous or unconvincing does not bring about the expected result. The appetitive powers must be equipped with (3) benevolence and (4) constancy. ${ }^{18}$

Although Buridan does not consider the fourth, executive function to be a part of prudence, he concludes by saying that some teachers divide it likewise into four parts: (1) providence, (2) vigilance, (3) diligence and (4) solicitude. ${ }^{19}$

This elaborate division of prudence serves the purpose of clarifying Buridan's answer, firstly, that prudence is a virtue which can be subdivided and, secondly, that the unity of prudence can be seen whereby its various parts are all needed, in order for a prudent action to emerge. It is, however, not quite clear whether the elaborate division plays a more fundamental philosophical role in Buridan's ethics and action theory, especially since he presents it as a theory of some other teachers. Some parts of this analysis, especially the executive function, are only briefly mentioned.

In the following I will nevertheless argue that the second and third functions are theoretically interesting and that they are related to other contexts of Buridan's commentary of EN, especially to Book VII. The syllogistic division of synesis is here relevant. Aristotle employs the practical syllogism already in his explanation of synesis, and he returns to the parts of the practical syllogism in a detailed manner when incontinent behaviour is explained in Book VII. Buridan's syllogistic organization of the parts of synesis relates the universal premise to the concrete opportunities expressed by the minor premise. In this sense synesis as rectum iudicium is an awareness of the concrete situation in its relationship to the universal norms of conduct. This awareness prompts the intellect (1) to find the proper general directive and the perception (2) to relate it to a particular circumstance.

It is essential to note that intellect (1) and sensus (2) are accompanied by their "twin" or "shadow" abilities of circumspection (3) and caution (4). These abilities increase the awareness of a prudent person in an important way. Their task is to

$18{ }^{18}$ Buridan 1513, $134 \mathrm{vb}$ : "Item dicunt illi quod pars praeceptiva ad hoc quod praeceptum sit bonus et utile requirit duo ex parte intellectus et duo ex parte appetitus. Ex parte enim intellectus requirit primo certam determinationem. Secundo requirit efficacem suasionem. Appetitus enim praeceptum formidabile non reciperet bene, neque praeceptum etiam non vallatum suasionibus. Ex parte enim appetitus requiritur primo benignitas ... Secundo requiritur constantia."

$19 \quad{ }^{19}$ Buridan 1513, $134 \mathrm{vb.}$ 
exclude the possible defects in the major and minor premises. Circumspection functions "by recollecting all circumstances" relevant to the formation of the major premise. Caution works by "distinguishing all eventual good and bad aspects related to action." ${ }^{20}$ Synesis thus, in principle, goes through all intellectual and perceptual aspects relevant in the situation. The shadow abilities serve the purpose of double-checking the situation: if, e.g., perception finds that some course of action ought to be followed, caution checks that there are no hidden side effects and that there is no other alternative course of action which would be even better.

As a profound awareness of both intellectual and perceptual matters synesis thus forms a judgment so that it is safeguarded against possible errors. Buridan's elaborate description leaves open the possibility that all defects may never be overcome: a deep awareness of all possible problems may lead to a situation in which the resulting judgment remains qualified or uncertain.

That this possibility is not only theoretical but also influences the concrete judgment is strengthened by the observation that the first requirement of the third, commanding function, is the certainty of determination. Also the second requirement, effective persuasion, points to the same issue: whereas the opposite of certainty is ambiguity, the opposite of effective persuasion is weak and unconvincing advice. ${ }^{21}$ The third, or commanding, function is that part of prudence which actually performs the practical syllogism. The two intellectual requirements of that function are conditioned by the outcome of synesis: if the judgment remains uncertain or unpersuasive, the commanding prudence does not work properly.

\section{Akrasia and Good Judgment in Buridan (Book VII, q6-8)}

Buridan's explanation of akrasia in Book VII, q6-8, concentrates on the role of iudicium in syllogistic reasoning. Although synesis is not explicitly mentioned, Buridan in fact outlines again the judicative part of prudence and is thus speaking on the same issues that are in Book VI, q18, gathered under synesis.

In the sixth question it is asked whether one can possess simultaneously contrary judgments concerning a particular action. ${ }^{22}$ The answer is negative, since the intellectual soul is a unity which must come to a unified judgment. In the process of answering Buridan employs the distinction between deliberative and judicative

$20 \quad{ }^{20}$ Buridan 1513, 134 va-vb (quoted above).

2121 Buridan 1513, $134 \mathrm{vb}$. Buridan employs the expressions "fatuus", "fatuitas" and "praeceptum formidabile". In the context he gives the opposite vice to all 12 (or 16) virtues of prudence.

${ }^{22}$ Buridan 1513, 142 va: "Utrum de aliquo operabili possint haberi simul contraria iudicia." 
prudence. Whereas the former collects and examines the "appearances", that is, information and reasons that stem from "things and circumstances", the latter is an intellectual power that makes a total judgment which is qualitatively more than the sum of appearances. ${ }^{23}$

Although the judgment thus differs from mere counsel, Buridan qualifies the ways in which the judgement becomes one. He says that it is not possible to have one judgement according to the senses and a contrary judgment according to the intellect. This is so because the intellect as a higher power necessarily overcomes the judgment of the senses. ${ }^{24}$ We note already here that like in Book VI, q18, both the senses and the intellect participate in the judicative activity of prudence as synesis.

In addition, Buridan admits that the final judgment sometimes remains "weak" (debile) or "faint" (formidabile seu formidinale). ${ }^{25}$ This is of course essential for the understanding of akratic behavior, since in the case of a weak judgment the person may act against better knowledge. Interesting for us in this context is, however, that this feature is related to the classification given in Book Vl, q18: in order that the command can be effective, both a determinatio certa and a suasio efficax are needed. The analysis of akrasia shows that this is not always the case, and therefore it is possible to act against some judgments.

Since deliberation, judgment and command are successive, the lack of certainty and conviction in the command have its origins in synesis: if the four virtues related to the practical syllogism are not working properly, the actual judgment lacks some qualities. Aristotle remarks in this context (EN 1142b18-20) that the akratic person can have a correct deliberation, which indicates that in such case the error first occurs when either synesis or command is concerned.

In q7 of Book VII, Buridan asks whether the akratic person knows when he is doing wrong. ${ }^{26}$ His final answer is that one cannot claim to know with an "actual,

${ }_{23}^{23}$ Buridan 1513, $143 \mathrm{rb}$ : "Dicam quod potest poni differentia inter apparentiam et iudicium, quantum saepe, ut mihi videtur, expertus sum, quod cum rationes viderem ad utramque partem probabiles, tamen ad neutram partem iudicii determinabam me, etiam neque novis rationibus ad unam partem, vel ad aliam supervenientibus, sed in suspenso tenebam me. Et iterum videmus non omnes aeque cito nec aeque intense consentire apparentiis, immo prudentis est prius examinare consilia. Apparentiae namque videntur se tenere ex parte rerum et circumstantiarum suarum. ludicium autem est actus ipsius intellectus circa apparentias, et nos videmus si voluntas ad unam partem afficiatur, quod intellectus plene iudicabit pro parte illa ex apparentia debilissima, nec apparentiae valde fortes poterunt ipsum movere ad aliam partem."

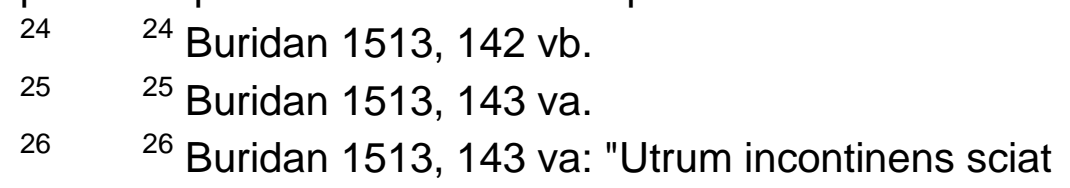


particular and complete knowledge" that he is doing wrong. The akratic person is sinning with an "incomplete" knowledge, in which something remains "ignored, inconsidered or incompletely judged." ${ }^{27}$ Thus the error is already to be found at its root either in eubulia (consideration/deliberation) or in synesis (judgment).

Concerning the syllogistic structure of the right judgment, Buridan pays attention to the interaction between intellect and sensus. The passions distract the senses of an akratic person. Although the intellect is a higher power, its capacity for judging also becomes hampered as a result of this distraction. This is why the akratic person can normally take all circumstances into consideration, but not while he is disturbed by passion. ${ }^{28}$

For Buridan, the possibility of akratic behavior stands or falls with the certainty of judgments concerning a particular action. As q8 of Book VII states, the will necessarily accepts a judgment which is totally certain:

Sixth, if someone judges that something is good for him according to a consistent good reason, so that it appears good according to all good reasons and so that nothing evil follows, then, it seems to me, if this judgment is uncertain (dubium), the will nevertheless does not necessarily accept it ... Seventh, if the judgment in question is totally certain (certum omnino), i.e., that the person firmly and sufficiently believes he sees all relevant circumstances and all their combinations, and, given all these combinations he firmly believes that the decision at hand will be good for him in any case and by no means bad, then I say that the will necessarily accepts it. And I do not consider a judgment made with certainty to be identical with true or scientific judgment; it is a judgment which is firmly believed and of which all faintness has been excluded (omni exclusa formidine) ${ }^{29}$

The judicative part of prudence works in this quote so that it checks all circumstances and aims at excluding all possible alternatives and their combinations. Both in content and in terminology this description is therefore very similar to the one given in Book VI, q18, as the description of synesis. The judicative part of prudence aims at

quando prave agit."

$27 \quad 27$ Buridan 1513, 144 ra-rb. See Saarinen, R.

Weakness of the Will in Medieval Thought. From Augustine to

Buridan. Leiden: Brill 1994, pp.178-180.

$28 \quad{ }^{28}$ Buridan 1513, 144 ra-rb: "... est bene notandum quod ille qui liberatus est ab omni passione sensitivi appetitus poteset magis omnes circumstantias attendere et cognoscere ... quam ille qui passione ligatus est. ... passiones sensitivi appetitus non sunt sine motu sanguinis aut aliorum humorum vel spirituum qui motus si sit magnus turbat sensum et prohibet ipsum intellectui debite monstrare, qui tamen intellectus de particularibus sensibilibus non potest vere et perfecte sine sensus convenienti ministerio iudicare."

$29 \quad{ }^{29}$ Buridan 1513, 145rb. Latin quote in Saarinen 1994, 181. 
producing a determination which is certain and thus can form a sufficient intellectual basis for the subsequent command to act. The akratic person fails to produce such a determination and therefore his good intention does not materialize.

In this context we do not outline Buridan's view of akrasia in detail. ${ }^{30} \mathrm{We}$ are only interested in looking at how the judicative act of prudence is relevant for Buridan's explanation of akratic behaviour. The relevance lies in the fact that sometimes the judgment remains incomplete or uncertain. To some extent this is a result of ignorance, but in addition it may also be a result of too much information: if the prudent person recollects all circumstances with necessary watchfulness and caution, the conflicting evidence may prevent her from forming a certain judgment. Of course this is a result of both information overload and ignorance at the same time: if the moral agent were omniscient, she could produce the final judgment with certainty. But since she is not omniscient but must nevertheless be cautious in a situation which is contingent and manifold, she may not reach a certain judgment. In a way the "shadow abilities" of watchfulness and caution thus prevent her from making a firm decision.

\section{Davidson and Buridan}

Let us now come back to the contemporary discussion and in particular to Donald Davidson's view of akrasia. Both Buridan and Davidson are discussing the conditions under which the "forward connection" between thought and action is operative. Moreover, they are both discussing the conditions of the judgment that prompts action. Aristotle's concept of synesis as good judgment offers a sophisticated conceptual platform for the medieval discussion.

When Buridan teaches that the virtues of watchfulness and caution belong to synesis and thus to the formation of good judgment, he focuses on the nature of this judgment as an all-things-considered judgment. It can be noted that Buridan even employs the Latin expression "prima facie" when he discusses the preconditions of a prudential action. In Book III, q3, he points out that it is often prudential to postpone a decision in order to investigate the case more closely. A prudent man does not accept immediately that which prima facie pleases him, but rather examines the eventual hidden consequences of available alternatives. ${ }^{31}$

3030 For other relevant factors in Buridan's view of akrasia, see Saarinen 1994.

3131 Saarinen 1994, 171. Buridan 1513, 42 va: "... libertas secundum quam voluntas potest non acceptare quod sibi praesentatum fuerit sub ratione boni, vel non refutare quod praesentatum est sub ratione mali, prodest valde nobis ad vitae directionem; pro tanto, quia in multis in quibus prima facie sunt aliquae rationes 
Both Buridan and Davidson see the possibility of akratic actions given by the fact that a conditional or a prima facie judgment does not necessarily materialize as action. We may judge that, prima facie, we had better to do this and nevertheless we may act otherwise. Of the two alternatives present in the akratic person's mind, the rationale for the akratic alternative prompts action, whereas the rationale for the virtuos deed does not, because it remains a conditional judgment.

This observation does not mean that Buridan's and Davidson's explanations of akrasia are identical. An important difference is given in the way Buridan treats an "all-things-considered" judgment. For Buridan, there comes a point in which additional consideration would no more be useful but which causes harmful delay. When this point has been reached, a prudential man begins to act. When he has considered all things well enough, the judgment starts to prompt action. In this sense an "all-things-considered" judgment is for Buridan no more a conditional or prima facie judgment, whereas it clearly remains that for Davidson.

This difference might, nevertheless, be a psychological one which pertains rather to the dynamics of action than to the logical structure of syllogistic reasoning. Both Buridan and Davidson teach that it is logically possible to act against a morally better judgment which is not absolute. Moreover, both focus keenly on the claim that practical reasoning and judgments concerning particular circumstances easily remain prima facie judgments. They do not reach the absolute certainty which is needed in order that the forward connection between judgment and action works properly. It is the logical nature of the underlying good judgment which enables akrasia or rules it out. At this level of logic and reasoning Buridan's and Davidson's explanations are similar.

I quoted earlier a contemporary philosopher who claimed that Davidson is the first philosopher "to focus attention on the notion of the prima facie in practical thinking." We have seen that the medieval thinkers in their elaboration of synesis and in their explanations of akrasia focus their attention both to the phenomenon of uncertain judgments and to the very notion of prima facie. There are of course rather large differences among the medieval philosophers: although he borrows the terminology of Thomas Aquinas, Buridan focuses on the uncertainty in a manner which is not found in Aquinas. Moreover, whereas Aquinas treats watchfulness and caution as virtues of commanding prudence, Buridan relates them to the emergence of judicative prudence and connects them with synesis. ${ }^{32}$ This is why I think that Davidson's distinction between prima facie and absolute judgments has its medieval counterpart rather in John Buridan than in Thomas Aquinas.

bonitatis apparentes, latent saepe mille malitiae, vel annexae, vel consequentes."

$32 \quad 32$ This is investigated in more detail in Saarinen (forthcoming). 
In this connection I will not, however, analyze the differences among the various medieval positions. I have just pointed out that the Aristotelian view of synesis as good judgment relates the medieval discussion to the problem according to which circumstances the good judgment is absolute or certain.

\section{The Theological Relevance of the "Forward Connection"}

The medieval discussion on "weakness of will" has recently been studied in two monographs. Whereas my own book deals with Commentaries on Aristotle's Ethics from Albert the Great to John Buridan, Bonnie Kent's valuable study Virtues of the Will pays attention to the same discussion in texts which are more theological than the commentaries. ${ }^{33}$ Some authors, like Thomas Aquinas, deal with akrasia in both philosophical and theological works, but many scholastics who did not write a commentary on Ethics nevertheless treated weakness of the will in their theological writings. Of these Kent analyzes, e.g., Walter of Bruges, Henry of Ghent, Peter Olivi and Richard of Middleton. ${ }^{34}$

One might think that these and other theological authors who stressed the relative autonomy of the will would have had problems with the Aristotelian forward connection between thought and action. Although this is true to a certain extent, Kent shows that all authors agree on some intellectualistic requirements, e.g. that we always will sub ratione boni and that $\sin$ is always preceded by some kind of ignorance. $^{35}$

Bonnie Kent shows that the theological discussion on akrasia towards the end of the 13th century took place between two doctrinal propositions of which one is voluntaristic and the other intellectualistic. On the one hand the 1277 Paris condemnation declared, among other things, that the will must at least be able to preserve its state of non velle when the natural mover prompts it towards an action. The other relevant doctrine was the so-called propositio magistralis of Giles of Rome which stated that "there is no evil in the will unless there is error or some lack of knowledge in reason." ${ }^{36}$

In my own study it can be seen that these two complementary doctrines were, to a great extent, followed in philosophical commentaries as well. For instance Buridan is very careful to outline the will's freedom in terms of the possibility of non velle. This

$33 \quad 33$ Saarinen 1994; Kent, B., Virtues of the Will:The Transformation of Ethics in the Late Thirteenth Century. Washington D.C.: The Catholic University of America Press 1995.

$34 \quad 34$ See esp. Kent 1995, 174-198.

$35 \quad 35$ Kent 1995, 175-182.

3636 Saarinen 1994, 166-168; Kent 1995, 76-81; 179-181. 
also contributed to his view that judgment does not necessarily prompt action but the will can stick to its right of veto in cases in which something remains inconsidered. ${ }^{37}$

Because in theological texts it was not necessary to deny the forward connection between thought and action as long as the will at least theoretically had a right of veto, the theological solutions of akrasia are in the last analysis rather similar to philosophical ones. Both proceed from the presupposition that something must be ignored or lacking, either in the deliberation or in the resulting judgment, or in both. The failure to will was preceded by a failure in prudential consideration. The forward connection thus did not lose its theoretical significance in theological contexts.

\section{Epistemic Akrasia}

As a last topic I will briefly discuss another related point which shows the wider theoretical significance of the medieval discussion for the history of philosophy. If we refine John Buridan's philosophical explanation of akrasia by means of a rational reconstruction, we easily come to the following conclusion: a particular action is almost always vulnerable to akrasia. For we cannot investigate all possible circumstances and cannot be infinitely cautious but simply must act without delay on the basis of available information. Only God who is omniscient is not vulnerable to akrasia.

If we carry this consideration further we might claim that akrasia is not only a moral problem but a universal problem of reasoning and decision-making. This step is taken by Jaakko Hintikka who says that "Aristotle's problem of akrasia is a facet of his general theories of reasoning and of potentiality; it is not a specifically moral problem for him." ${ }^{38}$ Hintikka has studied Leibniz's modal theory. He comes to the conclusion that the modern modal theory opens doors to an even wider conception of akrasia. When Leibniz says: "God is, necessarily, a being who wills the best, but not a being who necessarily wills the best," we may, according to Hintikka, ask whether even God has the theoretical possibility to will or act against better judgment, in other

$37 \quad 37$ Saarinen 1994, 166-172.

38 Hintikka, J., "Was Leibniz's Deity an Akrates?" In: Modern Modalities, ed. S.

Knuuttila, pp. 85-108. Dordrecht: Kluwer; here: p. 96. The phenomenon of epistemic akrasia can be found in Hintikka 1988; the term is employed by Hookway, C. "Epistemic akrasia and epistemic virtue", forthcoming in: Virtue Epistemology, ed. A. Fairweather and L. Zagzebski. (also in: www.shef.ac.uk/uni/academia/N-Q/phil/department/staff/hookway/akrasia.htm as of April 2002) Hookway (op.cit. n.p.) describes epistemic akrasia as follows: "if someone consciously accepts some proposition while also accepting that it is epistemically wrong to do so". 
words, to act akratically. ${ }^{39}$

Returning from Hintikka's theological consideration to philosophy, we may ask the following: if we change our understanding of science from the Aristotelian paradigm to the modern one, the problems which the Aristotelians related to the inductive and perceptual nature of ethics begin to permeate the emerging empirical sciences as a whole. Given that modern science is based on empirical observation of the particulars and the judgments concerning them, how much evidence should we gather, in order to be safe from the error of judging the matter too quickly? We are not omniscient and we cannot be infinitely watchful and cautious. Therefore we remain vulnerable to errors of insufficient evidence and hasty judgment. The empiricist's problem of hasty judgment resembles the old problem of akrasia, but it is not related to moral philosophy, but rather to empirical knowledge in general. Thus we are dealing with the claim that akrasia is fundamentally a logical or epistemic problem instead of a moral one.

John Buridan's discussion on the fundamentally uncertain nature of the judgments which synesis makes, relying on the contributive role of particular facts, already points towards this kind of inductive decision-making theory. One important feature of the late medieval discussion on prudence, synesis and akrasia is that the particular action must be deliberated and judged without any presupposition of omniscience. The moral agent must make a judgment without knowing everything.

This lack of omniscience is also relevant for the modern philosophy of science. In his book Pluralism: Against the Theory of Consensus (1993) Nicholas Rescher criticizes Jürgen Habermas and the so-called consensus theory of truth as follows: the consensus theory presupposes a scientific community which is potentially omniscient. But this presupposition is obviously false. The particular and limited nature of human beings effectively hinders omniscience and thus makes consensus unavailable. When scientists investigate and debate informative claims, they

do (and must) proceed on the basis of a 'perspective' -- a 'cognitive stance' or 'point of view' regarding evidential/ methodological matters from which the issues are judged. We cannot call upon the Recording Angel to inform us in matters of inquiry, but have to proceed with the instruments and materials at our disposal to make the best judgements that we can manage to achieve. ${ }^{40}$

In his criticism of Habermas, Nicholas Rescher concludes that scientific judgments are not and should not be absolute judgments but that they are "best judgments" connected with the available, although limited, evidence. This state of

\footnotetext{
$39 \quad{ }^{39}$ Hintikka 1988, 98.

$40 \quad 40$ Rescher, N., Pluralism: Against the Demand for Consensus. Oxford: Clarendon Press, 1993, p. 77.
} 
affairs necessarily prompts pluralism, since different judgment can only partially be falsified or reconciled with one another. Pluralism does not, however, mean relativism or skepticism for Rescher. He argues that within the pluralist situation the scientist should prefer the best explanation, granted that inerrancy is not reached. ${ }^{41}$

We may say, in accordance with both Donald Davidson and Nicholas Rescher, that empirical judgments for the same reason leave the door open for epistemic akrasia. This modern conclusion is not very different from John Buridan's medieval interpretation of moral akrasia. People think and act akratically because they are not omniscient recording angels but agents who make their decisions on the basis of incomplete, particular and perspective-related evidence.

41 Rescher 1993, 98-99. 